Journal of Telenursing (JOTING)

Volume 2, Nomor 1, Juni 2020

e-ISSN: 2684-8988

p-ISSN: 2684-8996

DOI: https://doi.org/10.31539/joting.v2i1.1129

\title{
NYERI PADA PASIEN POST OP FRAKTUR EKSTREMITAS BAWAH DENGAN PELAKSANAAN MOBILISASI DAN AMBULASI DINI
}

\author{
Juli Andri ${ }^{1}$, Henni Febriawati ${ }^{2}$, Padila $^{3}$, Harsismanto, $\mathrm{J}^{4}$, Rahayu Susmita ${ }^{5}$ \\ Universitas Muhammadiyah Bengkulu ${ }^{1,2,3,4,5}$ \\ juli_andri0788@yahoo.co.id ${ }^{1}$
}

\begin{abstract}
ABSTRAK
Tujuan dari penelitian ini untuk mengetahui hubungan antara tingkat nyeri dengan pelaksanaan mobilisasi dini dan ambulasi dini pada pasien post op fraktur eksremitas bawah di ruang Seruni RSUD dr. M. Yunus Bengkulu. Desain penelitian yang digunakan dalam penelitian ini adalah desain cross sectional. Hasil penelitian, pasien yang melakukan kegiatan mobilisasi berjumlah $82,9 \%$ dan pasien yang tidak melakukan kegiatan mobilisasi berjumlah $17,1 \%$, pasien yang melakukan kegiatan ambulasi berjumlah $82,9 \%$ dan pasien yang tidak melakukan kegiatan ambulasi berjumlah $17,1 \%$, nyeri sedang berjumlah $77,1 \%$ dan nyeri berat berjumlah 22,9\%. Pada hasil uji chi square, nilai $\mathrm{p}$ value $=0.000$. Simpulan, ada hubungan pelaksanaan mobilisasi dan ambulasi dini dengan nyeri pada pasien post op fraktur ekstremitas bawah di RSUD Dr. M. Yunus.
\end{abstract}

Kata Kunci: Ambulasi Dini, Mobilisasi, Nyeri

\section{ABSTRACT}

The purpose of this study was to determine the relationship between the level of pain with the implementation of early mobilization and early ambulation in post-op fracture patients with lower extremities in the Seruni room of RSUD dr. M. Yunus, Bengkulu. The research design used in this study was a cross-sectional design. The results of the study, patients who did mobilization activities amounted to $82.9 \%$. Patients who did not mobilize to $17.1 \%$ of patients who carried out ambulation activities amounted to $82.9 \%$. Patients who did not perform ambulation activities amounted to $17.1 \%$, pain moderate amounted to $77.1 \%$, and severe pain amounted to $22.9 \%$. In the chi-square test results, the value of $p$-value $=0,000$. In conclusion, there is a correlation between the implementation of mobilization and early ambulation with pain in post-op patients with lower limb fractures at RSUD Dr. M. Yunus.

Keywords: Early Ambulation, Mobilization, Pain

\section{PENDAHULUAN}

World Health Organization (WHO) mengemukakan bahwa kecelakaan lalu lintas merupakan penyebab kematian nomor 8 dan merupakan penyebab kematian teratas pada penduduk usia 15 - 29 tahun di dunia dan jika tidak ditangani dengan serius pada tahun 2030 kecelakaan lalu lintas akan meningkat menjadi penyebab kematian kelima di dunia. Pada tahun 2011- 2012 terdapat 5,6 juta orang meninggal dunia dan 1,3 juta orang menderita fraktur akibat kecelakaan lalu lintas (Desiartama \& aryana, 2017). 
Insiden fraktur femur di Indonesia merupakan yang paling sering yaitu sebesar $39 \%$ diikuti fraktur humerus (15\%), fraktur tibia dan fibula $(11 \%)$, dimana penyebab terbesar fraktur femur adalah kecelakaan lalu lintas yang biasanya disebabkan oleh kecelakaan mobil, motor, atau kendaraan rekreasi $(62,6 \%)$ dan jatuh $(37,3 \%)$ dan mayoritas adalah pria (63,8\%).4,5\% puncak distribusi usia pada fraktur femur adalah pada usia dewasa (15 - 34 tahun) dan orang tua (diatas 70 tahun) (Risnah et al., 2019).

Fraktur dapat menyebabkan komplikasi, morbiditas yang lama dan juga kecacatan apabila tidak mendapatkan penanganan yang baik (Padila, 2012). Komplikasi yang timbul akibat fraktur antara lain perdarahan, cedera organ dalam, infeksi luka, emboli lemak dan sindroma pernafasan. Banyaknya komplikasi yang ditimbulkan contohnya diakibatkan oleh tulang femur adalah tulang terpanjang, terkuat, dan tulang paling berat pada tubuh manusia dimana berfungsi sebagai penopang tubuh manusia. Selain itu pada daerah tersebut terdapat pembuluh darah besar sehingga apabila terjadi cedera pada femur akan berakibat fatal (Desiartama \& Aryana, 2017).

Fraktur terjadi akibat trauma, beberapa fraktur terjadi secara sekunder akibat proses penyakit seperti osteoporosis yang menyebabkan fraktur-fraktur yang patologis. Fraktur dibagi berdasarkan dengan kontak dunia luar, yaitu meliputi fraktur tertutup dan terbuka. Fraktur tertutup adalah fraktur tanpa adanya komplikasi, kulit masih utuh, tulang tidak keluar melalui kulit. Fraktur terbuka adalah fraktur yang merusak jaringan kulit, karena adanya hubungan dengan lingkungan luar, maka fraktur terbuka sangat berpotensi menjadi infeksi (Asrizal, 2014; Rahmawati et al., 2018).

Fraktur pada ekstremitas atas dan bawah dapat menyebabkan perubahan pada pemenuhan aktivitas. Perubahan yang timbul diantaranya adalah terbatasnya aktivitas, karena rasa nyeri akibat tergeseknya saraf motorik dan sensorik, pada luka fraktur (Smeltzer \& Bare, 2013).

Hasil studi yang dilakukan oleh Rahmawati et al., (2018) menyatakan bahwa sebagian besa kualitas hidup pasien fraktur terganggu pada domain fungsi fisik dan keterbatasan fisik, sedangkan kualitas hidup ditinjau dari mental secara keseluruhan baik. Diperlukan edukasi untuk meningkatkan kualitas hidup pasien pasca operasi. Salah satu tanda dan gejala dari fraktur adalah nyeri. Nyeri merupakan gejala yang paling sering ditemukan pada gangguan muskoskeletal. Nyeri merupakan pengalaman sensorik atau emosional yang berkaitan dengan kerusakan jaringan aktual atau fungsional, dengan onset mendadak atau lambat (SDKI, 2016).

Hambatan mobilitas fisik adalah keterbatasan ekstremitas atas maupun bawah dalam bergerak secara mandiri dan terarah. Batasan karakteristik kesulitan mengubah posisi, keterbatasan rentang gerak sendi, melakukan aktivitas lain dengan dibantu orang lain, pergerakan lambat. Sedangkan faktor berhubungannya yaitu kerusakan integritas tulang, adanya gangguan muskuloskeletal, kerusakan pada integritas struktur tulang, adanya program pembatasan gerak (Wiley \& Sons, 2015).

Penatalaksanaan fraktur tersebut dapat mengakibatkan masalah atau komplikasi seperti kesemutan, nyeri, kekakuan otot, bengkak atau edema serta pucat pada anggota gerak yang dioperasi (Carpintero et al., 2014). Masalah tersebut dapat disebabkan oleh beberapa faktor salah satunya adalah kurang atau tidak dilakukannya mobilisasi dini pasca pembedahan (Lestari, 2014). Beberapa literatur menyebutkan bahwa pentingnya melakukan mobilisasi dini yaitu untuk memperbaiki sirkulasi, mencegah terjadinya masalah atau komplikasi setelah operasi serta mempercepat proses pemulihan pasien (Keehan et al., 2014). 
Mobilisasi merupakan kemampuan setiap individu untuk bergerak secara bebas, mudah dan teratur dengan tujuan untuk memenuhi kebutuhan aktivitas guna mempertahankan kesehatannya (Wahyudi \& Wahid, 2016). Kehilangan kemampuan untuk bergerak menyebabkan ketergantungan dan ini membutuhkan tindakan keperawatan. Mobilisasi diperlukan untuk meningkatkan kemandirian diri, meningkatkan kesehatan, memperlambat proses penyakit khusunya penyakit degeneratif dan untuk aktualisasi diri (Wahyudi \& Wahid, 2016).

Hasil penelitian Lestari (2014) menyebutkan bahwa mobilisasi dini atau pergerakan yang dilakukan sesegera mungkin akan berpengaruh pada proses penyembuhan dan lamanya hari rawat.

Berdasarkan Survey awal yang peneliti lakukan selama berada di ruang seruni selama 3 hari terhadap 12 orang pasien yang mengalami Fraktur di ekremitas bagian bawah, 5 orang mengatakan tidak berani melakukan miring kanan dan miring kiri (tindakan mobilisasi) dikarenakan takut jahitan luka operasi nya lepas, dan 7 orang pasien mengatakan melakukan mobilisasi sesuai anjuran perawat ruangan, didapatkan hasil bahwa pasien yang mau melakukan mobilisasi dini dan ambulasi mengalami nyeri ringan pada post operasi hari ke 3 dan 4, sementara pasien yang tidak mau melakukan atau taukut melakukan mobilisasi dan ambulasi mengalami nyeri sedang sampai berat.

\section{METODE PENELITIAN}

\section{Jenis dan Rancangan penelitian}

Jenis penelitian ini adalah survey analitik dengan metode cross sectional dimana penelitian ini digunakan untuk melihat hubungan variable independent (Mobilisasi post op fraktur eksremitas bawah) dengan variabel dependent (tingkat nyeri) dengan observasi atau pengukuran di lakukan sekaligus dalam kurun waktu yang sama.

\section{Populasi dan Sampel Populasi}

Populasi penelitian ini adalah seluruh pasien post op fraktur ekstremitas bawah di RSUD Dr. M. Yunus Bengkulu.

\section{Sampel}

Sampel yang diambil adalah pasien post op fraktur ekstremitas bawah di ruang Seruni RSUD dr.M.Yunus yang berjumlah 35 orang. Kriteria yang ditentukan oleh peneliti adalah : Pasien Post Op fraktur ekstremitas bawah yang dirawat di RSUD Dr. M. Yunus Bengkulu, kesadaran kompos mentis dengan nilai GCS 13-15, bersedia menjadi responden dan tidak ada komplikasi seperti perdarahan dll.

\section{HASIL PENELITIAN Analisa Univariat}

Tabel. 1

Gambaran Distribusi Frekuensi Mobilisasi pada

Pasien Post Op Fraktur Ekstremitas Bawah

\begin{tabular}{ccc}
\hline Kegiatan mobilisasi & Frekuensi & Persentase \\
\hline Ya & 29 & $82,9 \%$ \\
Tidak & 6 & $17,1 \%$ \\
\hline Total & 35 & $100 \%$ \\
\hline
\end{tabular}


Berdasarkan tabel 1 menunjukkan bahwa dari 35 responden sebagian besar mengikuti kegiatan mobilisasi, yaitu sebanyak 29 responden $(82,9 \%)$.

Tabel. 2

Gambaran Distribusi Frekuensi Ambulasi pada

Pasien Post Op Fraktur Ekstremitas Bawah

\begin{tabular}{ccc}
\hline Kegiatan Ambulasi & Frekuensi & Persentase \\
\hline Ya & 29 & $82,9 \%$ \\
Tidak & 6 & $17,1 \%$ \\
\hline Total & 35 & $100,0 \%$ \\
\hline
\end{tabular}

Berdasarkan tabel 2 menunjukkan bahwa dari 35 responden sebagian besar mengikuti kegiatan ambulasi, yaitu sebanyak 29 responden $(82,9 \%)$.

Tabel. 3

Gambaran Distribusi Frekuensi Tingkat Nyeri (Pre) pada Pasien Post Op Fraktur Ekstremitas Bawah

\begin{tabular}{lcc}
\hline \multicolumn{1}{c}{ Intensitas nyeri } & Frekuensi & Prosentase $\%$ \\
\hline Tidak nyeri & 0 & 0 \\
Nyeri ringan & 0 & 0 \\
Nyeri sedang & 0 & 0 \\
Nyeri berat & 24 & $68,6 \%$ \\
Nyeri sangat berat & 11 & $31,4 \%$ \\
\hline Total & 35 & $100,0 \%$ \\
\hline
\end{tabular}

Berdasarkan tabel 3 terlihat bahwa dari 35 pasien post op fraktur ekstremitas bawah di ruang Seruni RSUD Dr. M.Yunus Bengkulu sebelum dilakukan intervensi sebagian besar mengalami nyeri berat berjumlah 24 orang dengan persentase $68,6 \%$.

Tabel. 4

Gambaran Distribusi Frekuensi Tingkat Nyeri (post) pada Pasien post op Fraktur Ekstremitas Bawah

\begin{tabular}{lcc}
\hline \multicolumn{1}{c}{ Intensitas nyeri } & Frekuensi & Prosentase $\%$ \\
\hline Tidak nyeri & 0 & 0 \\
Nyeri ringan & 0 & 0 \\
Nyeri sedang & 27 & $77,1 \%$ \\
Nyeri berat & 8 & $22,9 \%$ \\
Nyeri sangat berat & 0 & 0 \\
\hline Total & 35 & $100 \%$ \\
\hline
\end{tabular}

Berdasarkan tabel 4 terlihat bahwa dari 35 pasien post op fraktur ekstremitas bawah di ruang Seruni RSUD Dr. M.Yunus Bengkulu setelah dilakukan intervensi sebagian besar mengalami nyeri sedang berjumlah 27 orang dengan persentase $77,1 \%$. 
Tabel. 5

Hubungan Pelaksanaan Mobilisasi dengan Nyeri pada Pasien Post Op Fraktur Ekstremitas Bawah

\begin{tabular}{|c|c|c|c|c|c|c|c|}
\hline \multirow{3}{*}{ Variabel } & \multicolumn{4}{|c|}{ Tingkat Nyeri } & \multirow{2}{*}{\multicolumn{2}{|c|}{ Total }} & \\
\hline & \multicolumn{2}{|c|}{$\begin{array}{c}\text { Nyeri } \\
\text { Sedang }\end{array}$} & \multicolumn{2}{|c|}{ Nyeri Berat } & & & Value \\
\hline & $\mathrm{N}$ & $\%$ & $\mathrm{~N}$ & $\%$ & $\mathrm{~N}$ & $\%$ & \multirow{4}{*}{0,000} \\
\hline Tidak Mobilisasi & 1 & 16,7 & 5 & 83,3 & 6 & 100 & \\
\hline Melakukan Mobilisasi & 26 & 89,7 & 3 & 10,3 & 29 & 100 & \\
\hline Total & 27 & 77,1 & 8 & 22,9 & 35 & 100 & \\
\hline
\end{tabular}

Berdasarkan tabel 5 hasil uji statistik menunjukkan bahwa ada hubungan antara pelaksanaan mobilisasi dengan nyeri pada pasien post op fraktur ekstremitas bawah dengan nilai $\mathrm{p}=0,000$.

Tabel. 6

Hubungan Pelaksanaan Ambulasi Dini dengan Nyeri pada Pasien Post Op Fraktur Ekstremitas Bawah

\begin{tabular}{|c|c|c|c|c|c|c|c|}
\hline \multirow{3}{*}{ Variabel } & \multicolumn{4}{|c|}{ Tingkat Nyeri } & \multirow{2}{*}{\multicolumn{2}{|c|}{ Total }} & \multirow{2}{*}{$\begin{array}{l}\text { P. } \\
\text { Value }\end{array}$} \\
\hline & \multicolumn{2}{|c|}{ Nyeri Sedang } & \multicolumn{2}{|c|}{ Nyeri Berat } & & & \\
\hline & $\mathrm{N}$ & $\%$ & $\mathrm{~N}$ & $\%$ & $\mathrm{~N}$ & $\%$ & \multirow{4}{*}{0,000} \\
\hline Tidak Ambulasi & 0 & 0 & 6 & 100 & 6 & 100 & \\
\hline Melakukan Ambulasi & 27 & 93,1 & 2 & 6,9 & 29 & 100 & \\
\hline Total & 27 & 77,1 & 8 & 22,9 & 35 & 100 & \\
\hline
\end{tabular}

Berdasarkan tabel 6 hasil uji statistik menunjukkan bahwa ada hubungan antara pelaksanaan ambulasi dini dengan nyeri pada pasien post op fraktur ekstremitas bawah dengan nilai $\mathrm{p}=0,000$.

\section{PEMBAHASAN}

\section{Analisa Univariat}

\section{Gambaran Distribusi Frekuensi Pelaksanaan Mobilisasi pada Pasien Post Op Fraktur Ekstremitas Bawah}

Dari hasil penelitian pada pasien post op fraktur ekstremitas bawah diruang Seruni RSUD dr. M. Yunus Bengkulu sebagian besar melakukan mobilisasi.

Hambatan mobilitas fisik adalah keterbatasan ekstremitas atas maupun bawah dalam bergerak secara mandiri dan terarah. Batasan karakteristik kesulitan mengubah posisi, keterbatasan rentang gerak sendi, melakukan aktivitas lain dengan dibantu orang lain, pergerakan lambat. Sedangkan faktor berhubungannya yaitu kerusakan integritas tulang, adanya gangguan muskuloskeletal, kerusakan pada integritas struktur tulang, adanya program pembatasan gerak (Wiley \& Sons, 2015).

Sejalan dengan penelitian yang dilakukan Ferdian at al., (2015) yang menyatakan bahwa mobilisasi dini berpengaruh terhadap intensitas nyeri pasien pasca bedah dengan general anestesi di RS Pani Wilasa Citarum.

Mobilisasi dini berperan penting pula untuk mengurangi nyeri dengan cara menghilangkan konsentrasi pasien pada lokasi nyeri atau daerah pembedahan, mengurangi aktivasi mediator kimiawi pada proses peradangan yang meningkatkan 
respon nyeri, serta meminimalkan transmisi saraf nyeri menuju saraf pusat (Pristahayuningtyas \& Kalimantan, 2016)

Pemberian mobilisasi dini menjadi penting karena telah dijadikan standar dalam prosedur Enhanced Recovery After Surgery (ERAS) (Dolgun et al., 2017). Mobilisasi dini mampu melancarkan sistem peredaran darah dan membantu system tubuh kembali normal dengan cepat.

Penelitian Agustin \& Purwanti (2017) menunjukkan bahwa tindakan mengubah posisi sesering mungkin atau tirah baring, mengajarkan pasien memposisikan tungkai dalam keadaan abduksi dengan memberikan bantal diantara kedua tungkai untuk menghindari adduksi, melatih aktivitas fungsional terbukti efektif dilakukan untuk pasien fraktur intertrochanter femur dengan hambatan mobilitas fisik dan data yang mendukung yaitu dengan evaluasi ke pasien yang terlihat mampu memposisikan duduk, mampu melakukan aktivitas fungsional.

\section{Gambaran Distribusi Frekuensi Pelaksanaan Ambulasi Dini pada Pasien Post Op Fraktur Ekstremitas Bawah}

Dari hasil penelitian pada pasien post op fraktur ekstremitas bawah diruang Seruni RSUD dr. M. Yunus Bengkulu sebagian besar melakukan ambulasi dini.

Konsep yang ada mengatakan bahwa ambulasi dini dapat membantu peningkatan mobilitas dalam pemenuhan kebutuhan sehari-hari, dalam penelitian Pashikanti \& Diane (2012) menunjukkan bahwa mobilisasi dini (khususnya ambulasi dini) pada populasi klien dengan tindakan pembedahan mengalami peningkatan dalam hasil yang diharapkan pada klien. Dalam penelitian ini yang mengalami peningkatan adalah intake makanan secara oral dan waktu defekasi terjadi lebih awal pada populasi yang dilakukan ambulasi dini, ditemukan bahwa jarak ketika latihan berjalan diantara 600$12.000 \mathrm{~m}$ pada kelompok ambulasi dan pada kelompok yang dilakukan bed-rest ratarata hanya $66 \mathrm{~m}$. Dalam penelitian ini juga ditemukan bahwa terjadi peningkatan nilai yang signifikan pada jumlah score pemenuhan ADL pada kelompok yang dilakukan ambulasi dini dibandingkan dengan kelompok yang tidak dilakukan ambulasi dini.

Penelitian Wulansari et al., (2017) menunjukkan bahwa tingkat ketergantungan seseorang akan meningkat setelah terjadinya trauma dan setelah dilakukan operasi. Hal ini juga terjadi pada penelitian ini, sebelum trauma klien dapat melakukan semua aktivitas sehari-hari dengan mandiri namun setelah fraktur dan sebelum dilakukan ambulasi dini terjadi peningkatan ketergantungan dalam pemenuhan ADL.

Penjelasan mengenai keuntungan ambulasi dini pada beberapa aspek dan juga berpengaruh pada pemenuhan ADL dapat menjadi pertimbangan untuk perawat untuk melakukan ambulasi dini secepat mungkin dengan pertimbangan kondisi klinis klien. Dari segi klien sendiri, yang menjadi pertanyaan bagi peneliti adalah faktor-faktor yang menyebabkan klien kooperatif dan mau melakukan ambulasi dini. Salah satu faktor yang menyebabkan klien kooperatif melakukan ambulasi dini adalah karakteristik responden yang melalukan ambulasi dini (Wulansari et al., 2017).

\section{Gambaran Distribusi Frekuensi Tingkat Nyeri (Pre) dan (Post) pada Pasien Post $O p$ Fraktur Ekstremitas Bawah}

Hasil penelitian menunjukkan bahwa sebelum dilakukan intervensi sebagian besar mengalami nyeri berat berjumlah 24 orang. Setelah dilakukan intervensi sebagian besar mengalami nyeri sedang berjumlah 27 orang. 
Terjadinya fraktur mengakibatkan adanya kerusakan syaraf dan pembuluh darah yang menimbulkan rasa nyeri. Nyeri terus menerus dan bertambah beratnya sampai fragmen tulang diimobilisasi. Nyeri yang timbul pada fraktur bukan semata-mata karena frakturnya saja, namun karena adanya pergerakan fragmen tulang. Untuk mengurangi nyeri tersebut, dapat diberikan obat penghilang rasa nyeri dan juga dengan teknik imobilisasi (tidak menggerakkan daerah yang fraktur) (Fakhrurizal, 2015).

Penatalaksanaan nyeri dilakukan membantu meredakan rasa nyeri dengan pendekatan farmakologi dan non farmakologi dengan cara lakukan pengkajian nyeri secara komprehensif, kendalikan faktor lingkungan yang dapat mempengaruhi respon pasien terhadap nyeri. Latihan ambulasi dini dan mobilisasi berfungsi untuk mengembalikan fungsi tubuh dan mengurangi nyeri karena dapat meningkatkan sirkulasi darah yang akan memicu penurunan nyeri.

\section{Hubungan Pelaksanaan Mobilisasi dan Ambulasi Dini dengan Nyeri pada Pasien Post Op Fraktur Ekstremitas Bawah}

Hasil uji statistik menunjukkan bahwa ada hubungan antara pelaksanaan mobilisasi danambulasi dini dengan nyeri pada pasien post op fraktur ekstremitas bawah dengan masing-masing nilai $\mathrm{p}=0,000$.

Upaya yang dilakukan untuk mengatasi nyeri dengan teknik relaksasi nafas dalam, ketidakefektifan perfusi jaringan perifer dengan instruksikan keluarga untuk mengobservasi kulit jika ada laserasi, kerusakan integritas kulit dengan mobilisasi pasien (ubah posisi pasien setiap dua jam sekali), hambatan mobilisasi fisik dengan damping dan bantu pasien saat mobilisasi dan bantu memenuhi kebutuhan sehari-hari, resiko infeksi dengan inspeksi kondisi luka atau insisi bedah dan ajarkan pasien dan keluarga tanda dan gejala infeksi, resiko syok (hipovolemik) dengan memonitor suhu dan pernafasan (Huda \& Kusuma, 2015; Alvinanta et al., 2019).

Untuk variabel ambulasi pasien yang melakukan ambulasi dengan tingkat nyeri sedang berjumlah 27 orang dengan persentase $93,1 \%$, pasien yang melakukan ambulasi dengan tingkat nyeri berat berjumlah 2 orang dengan persentase $6,9 \%$ sedangkan pasien yang tidak melakukan ambulasi dengan tingkat nyeri berat berjumlah 6 orang dengan persentase $100 \%$.

Nyeri post pembedahan akan timbul setelah hilangnya efek dari pembiusan, nyeri hebat akan dirasakan 24 jam pertama atau hari ke dua post pembedahan baik pasien yang baru pertama kali dilakukan pembedahan sebelumnya maupun yang sudah berulang kali dilakukan pembedahan (Bahrudin, 2018). Anastesi regional merupakan salah satu upaya penurunan nyeri pada pasien post pembedahan dibandingkan dengan anastesi umum. Upaya lain dalam mengantisipasi nyeri post pembedahan adalah dengan edukasi pra pembedahan. Di sini, dijelaskan bahwa edukasi yang baik yang spesifik sesuai dengan kebutuhan pasien, melibatkan pendukung pasien dan menggunakan pendekatan personal (Chou et al., 2016).

Hasil tersebut didukung penelitian yang dilakukan Wulandari yang menunjukkan nilai signifikansi sebesar $\mathrm{p}=0,000$, membuktikan bahwa terdapat pengaruh mobilisasi dini terhadap nyeri post operasi TURP pada pasien BPH, kesamaan lain dalam penelitian ini yaitu pada jenis anestesi yang diberikan pada responden post pembedahan yaitu anestesi regional (Wulandari, 2018). 
Hasil penelitian Lestari (2014) menyebutkan bahwa mobilisasi dini atau pergerakan yang dilakukan sesegera mungkin akan berpengaruh pada proses penyembuhan dan lamanya hari rawat.

Penelitan ini sejalan dengan Ditya et al., (2016) bahwa mobilisasi dini dapat mempertahankan fungsi tubuh, mempertahankan tonus otot, dan memulihkan pergerakan sedikit demi sedikit sehingga pasien post pembedahan dapat memenuhi kebutuhan aktivitasnya kembali.

Mobilisasi merupakan kemampuan individu untuk bergerak secara bebas, mudah dan teratur dengan tujuan untuk memenuhi kebutuhan aktivitas guna mempertahankan kesehatannya (Wahyudi \& Wahid, 2016). Kehilangan kemampuan untuk bergerak menyebabkan ketergantungan dan ini membutuhkan tindakan keperawatan. Mobilisasi diperlukan untuk meningkatkan kemandirian diri, meningkatkan kesehatan, memperlambat proses penyakit khusunya penyakit degeneratif dan untuk aktualisasi diri (Wahyudi \& Wahid, 2016).

Beberapa literatur menyebutkan bahwa pentingnya melakukan mobilisasi dini yaitu untuk memperbaiki sirkulasi, mencegah terjadinya masalah atau komplikasi setelah operasi serta mempercepat proses pemulihan pasien (Keehan et al., 2014).

\section{SIMPULAN}

Ada hubungan yang bermakna antara pelaksanaan mobilisasi dan ambulasi dini dengan nyeri pada pasien post op fraktur ekstremitas bawahdi ruang Seruni RSUD Dr. M. Yunus Bengkulu.

\section{SARAN}

Hasil penelitian dapat memberikan suatu masukan bagi Rumah Sakit dan evaluasi dalam pelaksanaan program yang telah dilaksanakan sehingga dapat meningkatkan pelayanan kesehatan terhadap pasien terutama pasien post op fraktur ekstremitas bawah.

Institusi pendidikan keperawatan hendaknya menambah referensi dan memberikan informasi tentang kegiatan mobilisasi dan ambulasi pada pasien post opfraktur khususnya bagi mahasiswa Keperawatan di Universitas Muhammadiyah Bengkulu.

\section{DAFTAR PUSTAKA}

Agustin, A., \& Purwanti, S. (2017). Upaya Peningkatan Mobilisasi pada Pasien Post Operasi Fraktur Intertrochanter Femur. Naskah Publikasi. Universitas Muhammadiyah Surakarta

Alvinanta, N. P., Widiastuti, H. P., \& Firdaus, R. (2019). Asuhan Keperawatan pada Pasien dengan Post Op Fraktur Ekstremitas Bawah di Ruang Cempaka RSUD Abdul Wahab Sjahranie Samarinda. Karya Tulis Ilmiah. Politeknik Kesehatan Kemenkes Kalimantan Timur

Asrizal, R. A. (2014). Closed Fracture 1/3 Middle Femur Dextra. Medula, 2(3)

Bahrudin, M. (2018). Patofisiologi Nyeri (Pain). Saintika Medika: Jurnal Ilmu Kesehatan dan Kedokteran Keluarga, 13(1), 7-13

Carpintero, P., Caeiro, J., Morales, A., Carpintero, R., Mesa, M., \& Silva, S. (2014). Complications of Hip Fractures: A Review. World Journal of Orthopedics, 5(4), $402-411$ 
Chou, R., Gordon, D. B., Casasola, O. A., Rosenberg, J. M., Bickler, S., \& Brennan, T. (2016). Guidelines on the Management of Postoperative Pain. The Journal of Pain, 17(2), 131-157

Desiartama, D., \& Aryana, A. (2017). Gambaran Karakteristik Pasien Fraktur Femur akibat Kecelakaan Lalu Lintas pada Orang Dewasa di Rumah Sakit Umum Pusat Sanglah Denpasar Tahun 2013. E-Jurnal Medika

Ditya, W., Asril, Z., \& Afriwardi, A. (2016). Hubungan Mobilisasi Dini dengan Proses Penyembuhan Luka pada Pasien Pasca Laparatomi di Bangsal Bedah Pria dan Wanita RSUP Dr M Djamil Padang. Jurnal Kesehatan Andalas, 5(3), 724-729

Dolgun, E., Meryem, Y. V. G., Arzu, A., \& Yasemin, A. (2017). The Investigation of Mobilization Times of Patients After Surgery. Asian Pacific Journal of Health Science, 4(1), 71-75

Fakhrurizal, A. (2015). Pengaruh Pembidaian terhadap Penurunan Rasa Nyeri pada Pasien Fraktur Tertutup di Ruang IGD Rumah Sakitumum Daerah A.M Parikesit Tenggarong. Jurnal Ilmu Kesehatan, 3(2)

Ferdian, A. S. O., Puguh, S. K., \& Supriyadi, S. (2015). Efektivitas SEFT dan Mobilisasi Dini terhadap Penurunan Nyeri pada Pasien Pasca Bedah dengan General Anestesi di RS Panti Wilasa Citarum Semarang. Jurnal Ilmu Keperawatan dan Kebidanan, 1-9

Huda, N. H., \& Kusuma, K. (2015). Aplikasi Asuhan Keperawatan Berdasarkan Diagnosis Medis dan Nanda NIC-NOC Jilid 2. Jogjakarta: Medication

Keehan, R., Kendrick, E., Flavell, E., \& Deglurkar, M. (2014). Enhanced Recovery for Fractured Neck of Femur: A Report of 3 Cases. Geriatric orthopaedic surgery \& rehabilitation, 5(2), 37-42

Lestari, Y. E. (2014). Pengaruh ROM Exercise Dini pada Pasien Post Operasi Fraktur Ekstermitas Bawah (Fraktur Femur dan Fraktur Cruris) terhadap Lama Hari Rawat di Ruang Bedah RSUD Gambiran Kota Kediri. Jurnal Ilmu Kesehatan, 3(1)

Padila, P. (2012). Buku Ajar Keperawatan Medikal Bedah. Yogyakarta: Nuha Medika

Pashikanti, L., \& Diane, A. V. (2012). Impact of Early Mobilization Protocol on the Medical-Surgical Inpatient Population. http://unmhospitalist.pbworks.com/w/fil e/fetch/66026941/Impact\%20of\%20Early\%20Mobilization\%20Protocol\%20o\%2 0the\%20MedicalSurgical\%20Inpatient\%20Population.pd

Pristahayuningtyas, R. C. Y., \& Kalimantan, J. (2016). Pengaruh Mobilisasi Dini terhadap Perubahan Tingkat Nyeri Klien Post Operasi Apendektomi di Rumah Sakit Baladhika Husada Kabupaten Jember. Pustaka Kesehatan, 4(1), 102-107

Rahmawati, R., Arif, M., \& Yuliano, A. (2018). Pengaruh Pembidaian terhadap Penurunan Skala Nyeri pada Pasien Fraktur Tertutup di Ruangan IGD RSUD Dr. Achmad Mochtar Bukittinggi Tahun 2018. Stikes Perintis Padang

Risnah, R., Risnawati, H. R., Azhar, M. U., \& Irwan, M. (2019). Terapi Non Farmakologi dalam Penanganan Diagnosis Nyeri Akut pada Fraktur: Systematic Review. Journal of Islamic Nursing, 4(2), 77-87

SDKI, DPP \& PPNI. (2016). Standar Diagnosis Keperawatan Indonesia: Definisi dan Indikator Diagnostik. Edisi 1. Jakarta: DPP PPNI

Smeltzer, S. C. \& Bare, B. G. (2013). Buku Ajar Keperawatan Medikal Bedah Brunner \& Suddarth, Edisi 8. Jakarta: EGC

Wahyudi, A. S., \& Wahid, A. (2016). Buku Ajar Ilmu Keperawatan Dasar. Jakarta: Mitra Wacana Media 
Wiley, J. \& Sons, S. (2015). Nursing Diagnoses-Definition and Classification 20152017. Jakarta: EGC

Wulandari, A. (2018). Pengaruh Mobilisasi Dini terhadap Nyeri Post Operasi TURP pada Pasien BPH di RS PKU Muhammadiyah Bantul. Retrieved from http://digilib.unisayogya.ac.id/3929/1/NASPUB BU ANI-1.pd

Wulansari, N. M. A., Ismonah, I., \& Shobirun, S. (2017). Pengaruh Ambulasi Dini terhadap Peningkatan Pemenuhan Activity Daily Living (ADL) pada Pasien Post Operasi Fraktur Ekstremitas di RSUD Ambarawa. Jurnal Ilmu Keperawatan dan Kebidanan (JIKK), III(1), 16-26 